\title{
Domestic Contestations against International Courts and Tribunals: Introduction to the Special Issue
}

\author{
Edouard Fromageau*, Machiko Kanetake**, Stephan Wittich ${ }^{* * *}$, and \\ Andrea Gattini****
}

\begin{abstract}
Domestic authorities, including national courts, at times, resist accepting the decisions of international courts and tribunals. The formal division between the national and international legal orders creates space for domestic authorities to contest or avoid international binding judicial decisions. The present special issue examines domestic contestations in multiple fields of international law, including human rights and investment law. In contesting some of the international decisions, domestic authorities invoke a wide range of legal bases in resisting the effect of international decisions. The contributions in the present issue examine various such argumentative bases of contestations. The contributions also consider whether domestic resistance could give rise to the opportunity for international courts and tribunals to critically reflect on their own decisions and underlying reasoning.
\end{abstract}

\section{INTRODUCTION: THEME OF THE SPECIAL ISSUE}

It was in 2006 that Anne-Marie Slaughter and William Burke-White published their article entitled 'The Future of International Law is Domestic' in the Harvard International Law Journal. ${ }^{1}$ They argued that the future of international law would lie in its ability to guide and direct domestic actors to act in prescribed ways. Fifteen years later, the article's general contention seems still to hold true. In a wide range of regulatory fields, such as human rights, crimes, investment, public health and

* University of Aberdeen, School of Law. Email: edouard.fromageau@abdn.ac.uk

** Utrecht University, School of Law. Email: m.kanetake@uu.nl

*** University of Vienna, Department of European, International and Comparative Law. Email: stephan.wittich@univie.ac.at

**** University of Padua, Law School

1 William Burke-White and Anne-Marie Slaughter, 'The Future of International Law is Domestic (or, The European Way of Law)' (2006) 47 Harvard International Law Journal 327. 
environmental conservation, international law prescribes rules governing, not necessarily state-to-state relations, but those at the domestic level.

The future that Slaughter and Burke-White depicted back then placed international courts and tribunals in a position to review the government's exercise of authority over individuals and corporations with regard to the matters which are primarily governed by domestic (public) law. This also means that the effectiveness of the decisions of international courts and tribunals often relies on the government's willingness to change its domestic law and practices. However, it is a well-known problem that at times, the decisions of international courts and tribunals have given rise to normative conflicts with a country's constitutional law or other norms and rules on the domestic level. To give effect to international judicial decisions may also be seen undemocratic.

Against this background, this special issue examines the domestic reception of the decisions of international courts and tribunals. Domestic resistance is probably as old as international courts themselves. This resistance can take many forms, both passive and active. Some forms of resistance are quite direct and visible. One may think, for example, of the decisions of the German Federal Constitutional Court on the relationship between domestic and EU fundamental rights protection. ${ }^{2}$ In this special issue, the contributors do not only shed light on lesser-known forms of contestation, but also categorize forms of domestic contestation, scrutinize the motives for contestation and, finally, evaluate the consequences of these actions.

\section{ROADMAP}

The contributions in this special issue approach the matter of domestic contestations from different angles just as the reasons for these contestations themselves vary. There may be technical pretences of legal dualism between international and domestic law, real or purported constitutional impediments, issues of non-compliance with, or blunt disrespect of, international decisions, or-perhaps as a more modified version of contestation - non-implementation, all of which, however, may in themselves imply their own legal justifications. To international lawyers, the most appealing scheme of domestic contestation probably is to go into the substance of an international decision and challenge its legal reasoning.

In this vein, Edoardo Stoppioni offers a discourse analysis based on relatively recent instances where domestic courts have contested the legal reasoning of the decisions of international and regional courts. His analysis leaves the bedrock of the 'traditional' liberal dialogue which tends to view domestic contestations of international decisions in a frequently derogatory way as a priori national-or parochial-resistance, a stance that would largely divide the legal world into a 'good cosmopolitan' international judiciary and a 'bad nationalistic' one on the domestic level. However, he does not follow the beaten path of critical legal studies but adopts a neo-Gramscian approach which examines domestic contestations as

2 Dana Burchardt, 'Backlash against the Court of Justice of the EU? The Recent Jurisprudence of the German Constitutional Court on EU Fundamental Rights as a Standard of Review' (2020) 21 German Law Journal 1. 
'counter-hegemonic' reactions that may validly serve as a 'check and balance' for the (re)constructive development of international law.

Martin Breuer looks at the increasing resistance of states towards the European Court of Human Rights, a tendency that at times even expresses a hostile attitude prompted perhaps by the Court's extensive reading of the European Convention. In doing so, he focuses on the problem of states refusing to implement decisions of the Court and introduces the distinct concept of 'principled resistance', which goes beyond mere disagreement by domestic authorities, for whatever reason, with the international decision.

Jorge Contesse and Gabriela Cristina Braga Navarro dedicate their contributions to domestic contestations of the Inter-American Court of Human Rights. Even more than the judicial activism of the European Court, the Inter-American Court has expanded its authority through a dynamic and progressive case law which may in some cases be viewed as judicial law-making. This development has put states on alert as to the 'danger' of 'undue interference' with their domestic regulatory autonomy. In his paper, Jorge Contesse looks at instances of resistance moving between pushback and backlash, and calls for constructive judicial engagement and interaction that should in his opinion come from within the Court in the first place.

Gabriela Cristina Braga Navarro scrutinizes the practice of (non-)compliance with decisions of the Inter-American Court on indigenous territorial rights and focuses on the remedy of compensation. In her detailed case study, she reveals the variety of legal, institutional and socio-economic variables that determine compliance. Her cautious and balanced analysis leads her to conclude that only a holistic approach to the complex issue of compliance in the sensitive area of indigenous rights to territory can assist in fully understanding why states do comply or not.

While all of the previous contributions focus on domestic contestations against permanent international courts and tribunals, the final paper by Relja Radovic deals with contestations advanced against arbitral tribunals. Particularly the system of investor-state arbitration has come under fire by domestic actors, if only for alleged want of legitimacy and other structural reasons, which however is not the kind of 'contestation' under scrutiny in this special issue. Rather, Relja Radović picks out a special phenomenon in the difficult relationship between international and domestic courts and tribunals, that is, the attitude of the latter towards the rules concerning 'jurisdictional regulation' as developed by the former. Despite the great potential of resistance by domestic courts against international arbitral awards, through means of challenge and review, the limited practice shows that domestic courts have largely, and with varying justifications, endorsed and even encouraged the creation of jurisdictional rules by investment tribunals. In a sense, Relja's paper closes the circle of the special issue in that his conclusions support Edoardo's thesis of transformative internationalism.

\section{CONCLUSION}

Overall, the special issue highlights the following three points that would be relevant for the broader analysis of domestic contestations over the decisions of international 
courts and tribunals. First, in terms of argumentative bases, both domestic and international law can serve as a basis or facilitator of domestic contestations against international courts and tribunals. Many contributions in this issue analyse such contestations within domestic courts in order to identify how judges justify their rulings which may not be in line with the decisions of international courts and tribunals. As Marten Breuer puts forward, there are some, albeit rare, structurally problematic forms of resistance where domestic courts rely on the supremacy of their domestic constitution with little room for compromise and adjustment.

International law can also be a medium for domestic resistance. As elucidated by Jorge Contesse, the Argentinian Supreme Court's judgment of February $2017^{3}$ provides an example where judges presented their own interpretation of international law concerning the competence of international courts and tribunals. Furthermore, human rights norms have also been invoked as a basis for domestic contestations. As examined by Edoardo Stoppioni, the Italian Constitutional Court's decision no 238/ $2014^{4}$ mobilized the constitutional right of access to justice. While the Court's reasoning was based upon the constitutional right, it is, in substance, connected to the right to access to justice under international law.

Second, the special issue reminds us that some of the explicit challenges to international courts and tribunals should not be used as the sole indicators for the overall effectiveness of international decisions. As illustrated by the article by Gabriela Cristina Braga Navarro, the effective implementation of the decisions of international courts and tribunals depends on a number of international and domestic variables, including the clarity of the decisions and socio-economic conditions of relevant states. Also, the modes of engagement vary depending on the domains of rules. For instance, and as already mentioned, Relja Radovićs contribution to investment law demonstrates that domestic courts have rather been supportive of the proliferation of arbitrator-made jurisdictional rules. As the articles by Breuer, Contesse, and Stoppioni indicate, a variety of justifications that domestic courts and non-judicial authorities employ in contesting the decisions of international courts and tribunals often have space for adjustment and compromise.

Finally, with regard to the normative evaluation of domestic contestations, the present special issue highlights the importance of the quality of engagement and justifications on the basis of which judges or non-judicial bodies contest international courts and tribunals. As we noted at the beginning, a wide range of regulatory fields has been governed by both international and national law, which creates the space for dialogue and mutual learning among domestic authorities and international courts and tribunals. Depending on the dialogic dynamics of domestic resistance,

3 Corte Suprema de Justicia de la Nación (CSJN) [National Supreme Court of Justice], 14 February 2017, 'Ministerio de Relaciones Exteriores y Culto s/ informe sentencia dictada en el caso 'Fontevecchia y D’Amico vs. Argentina' por la Corte Interamericana de Derechos Humanos', CSJN 368/1998 (34-M) / CS1 (Argentina). See Contesse in this special issue.

4 Corte costituzionale (Constitutional Court), Sentenza no 238, Anno 2014 (22 October 2014) (Italy), English translation available at: <www.cortecostituzionale.it/documenti/download/doc/recent_judg ments/S238_2013_en.pdf $>$ (accessed on 10th June 2021). See Stoppioni in this special issue. 
national contestations can serve as a space for signalling some of the problematic characteristics of international courts and tribunals. In order for such a signal to be workable, domestic contestations should be constructed in such a manner that they would be appealing to some of the underlying normative foundations of the international legal order. 